\title{
Bahan Ajar Menulis Cerita Pendek Bermuatan Nilai-Nilai Kenabian untuk Siswa MTs Kelas VII
}

\author{
Rahma Anugraheny ${ }^{1}$, Muakibatul Hasanah ${ }^{1}$, Wahyudi Siswanto ${ }^{1}$ \\ ${ }^{1}$ Pendidikan Bahasa Indonesia-Universitas Negeri Malang
}

\begin{tabular}{l}
\hline \hline INFO ARTIKEL \\
\hline Riwayat Artikel: \\
Diterima: $30-11-2018$ \\
Disetujui: $17-02-2019$ \\
\hline
\end{tabular}

\section{Kata kunci:}

teaching materials;

short story;

prophetic values;

bahan ajar;

cerita pendek;

nilai-nilai kenabian

\author{
Alamat Korespondensi: \\ Rahma Anugraheny \\ Pendidikan Bahasa Indonesia \\ Universitas Negeri Malang \\ Jalan Semarang 5 Malang 65145 \\ E-mail: rahmaanugraheny18@gmail.com
}

\section{ABSTRAK}

Abstract: Teaching materials are the most important component in learning. This research and development aims to produce products and test the validity, systematics, communicativeness, and attractiveness of short story writing teaching materials with prophetic values. This study adapted the seven steps of the Borg and Gall development model, namely (1) information collection, (2) planning, (3) product development, (4) initial field trials, (5) initial product revisions, (6) field trials, (7) final product revisions. The results of the effectiveness test obtained a value of $t=7.191$ with sig. 0,000 which means $<0.05$. Thus, the score of students has increased significantly in writing short stories after using teaching materials to write short stories containing prophetic values.

\begin{abstract}
Abstrak: Bahan ajar merupakan komponen terpenting dalam pembelajaran. Penelitian dan pengembangan ini bertujuan untuk menghasilkan produk dan menguji validitas, sistematika, kekomunikatifan, dan kemenarikan bahan ajar menulis cerita pendek bermuatan nilai-nilai kenabian. Penelitian ini mengadaptasi tujuh langkah model pengembangan Borg dan Gall, yaitu (1) pengumpulan informasi, (2) perencanaan, (3) pengembangan produk, (4) uji coba lapangan awal, (5) revisi produk awal, (6) uji coba lapangan, (7) revisi produk akhir. Hasil uji keefektifan didapat nilai t = 7,191 dengan sig. 0,000 yang berarti $<0,05$. Dengan demikian, skor peserta didik mengalami peningkatan dalam menulis cerita pendek secara signifikan setelah menggunakan bahan ajar menulis cerita pendek bermuatan nilai-nilai kenabian.
\end{abstract}

Bahan ajar dalam pembelajaran adalah sarana belajar dalam wujud buku teks yang efisien digunakan dalam pembelajaran. Bahan ajar disusun agar dapat mempermudah dan mengarahkan aktivitas belajar sesuai dengan kompetensi yang akan diajarkan guru dan dikuasai peserta didik. Bahan ajar secara fungsional berguna dalam persiapan, kegiatan, dan penilaian pembelajaran. Bahan ajar harus berisi materi, pesan, dan isi mata pelajaran yang sesuai dengan disiplin ilmu dan informasi lain. Salah satu keterampilan dalam pembelajaran bahasa yang menuntut kreativitas tinggi ialah keterampilan menulis. Hal tersebut karena kegiatan menulis memerlukan latihan yang terus-menerus dan berkelanjutan agar mampu mengembangkan kreativitas menulis (Mustofa, 2014). Oleh karena itu, pembelajaran menulis perlu dirancang agar memperoleh hasil yang maksimal. Berdasarkan pemaparan tersebut, maka dapat disimpulkan bahwa menulis bukanlah hal yang mudah. Menulis tidak sekadar menghasilkan pemikiran yang kreatif dan menciptakan pengalaman dalam bentuk tulisan, tetapi lebih esensial ialah tulisan dapat dipahami dan bermakna bagi pembaca. Kesulitan dalam menulis dapat terjadi.

Menurut McVey (2008), kesulitan peserta didik dalam menulis, yaitu (1) masalah kemampuan tentang tata bahasa, peserta didik biasanya tidak yakin tentang ejaan dan saat memotong kalimat, mereka merasa kesulitan untuk membedakan antara genre dan gaya penulisan, dan (2) masalah keterlibatan, peserta didik biasanya memiliki masalah dalam menulis dikarenakan membaca, bahan bacaan sedikit maka akan menghasilkan tulisan yang sedikit dan membaca juga dianggap sebagai sebuah tugas, bukan hal yang harus dinikmati. Menulis tidak hanya sekadar menyalurkan pengalaman, tetapi yang harus diperhatikan ialah tulisan dapat dipahami dan bermakna. Cerita pendek cocok dijadikan sebagai salah satu bahan atau materi pembelajaran guna pembentukan karakter. Pendidikan yang diberikan di rumah dan di sekolah belum dapat dijadikan tonggak perubahan karakter yang diinginkan dari peserta didik. Perubahan karakter tersebut dapat terealisasi jika peserta didik mampu untuk mengubah pandangannya sendiri tentang kehidupan.

Cerita pendek memiliki beragam manfaat. Musfiroh (2008) memaparkan bahwa manfaat cerita pendek, yaitu (1) dapat membantu membentuk kepribadian, (2) tempat mencurahkan khayalan, (3) melatih komunikasi, (4) membangkitkan keinginan menulis dan membaca, dan (5) menambah wawasan. Cerita pendek untuk membantu pembentukan pribadi dan moral berkaitan erat dengan pembentukan karakter. Peserta didik biasanya hanya diminta membayangkan pengalaman pribadinya sebelum 
menulis. Dewey (2008) mengemukakan bahwa pengalaman tidak dapat langsung disamakan dengan pendidikan karena tidak semua pengalaman benar-benar mengandung pendidikan. Pengalaman yang kurang mendidik mengakibatkan kurangnya kepekaan dan membatasi pemikiran tentang masa depan karena keseharian hanya berdasarkan perasaan. Oleh karena itu, dalam pendidikan hendaknya memilih jenis pengalaman yang bermanfaat untuk peserta didik. Peserta didik memiliki cara yang berbeda dalam belajar. Oleh karena itu, pendidik juga harus menyesuaikan strategi mengajar yang tepat (Thomson, 2013).

Pendidikan dan pembelajaran yang diberikan di rumah dan di sekolah belum tentu dapat dijadikan tonggak perubahan karakter yang diinginkan dari peserta didik. Perubahan karakter tersebut dapat terealisasi jika peserta didik mampu untuk mengubah pandangannya sendiri tentang kehidupan. Oleh karena itu, nilai-nilai kenabian diharapkan dapat berperan dalam pembentukan karakter sesuai dengan perkembangan kognitif peserta didik. Tugas pendidikan adalah memelihara nilai-nilai kenabian untuk menumbuhkan tanggung jawab yang maknanya lebih luas dari sekadar berkomunikasi (Slattery, 2014). Pendidikan karakter dan muatan nilai-nilai kenabian terlihat sama dari substansi isi yang disisipkan dalam pembelajaran, tetapi terdapat perbedaan antara keduanya, yaitu pendidikan karakter diperoleh dari kumpulan nilai-nilai universal yang biasa digunakan oleh agama selain Islam, sedangkan nilai-nilai kenabian diperoleh dari sikap teladan yang dicontohkan Nabi Muhammad SAW. Pendidikan mengarahkan pembelajaran kepada hubungan manusia dan Tuhan sebagai tujuan akhir seorang individu (Glenn, 2012)

Penelitian ini menggunakan pendekatan pembelajaran berbasis teks dan proyek. Pembelajaran berbasis teks menganggap kegiatan menulis bukan hanya sebuah proses ekspresif, tetapi sebuah bentuk respon terhadap sosial (Hyland, 2005). Dimensi sosial merupakan bagian integral dari cita-cita humanistik yang kekuasaan penalaran manusia, akuntabilitas etika, dan kebebasan spiritual akan terpelihara (Ibrahim, 2017). Hal tersebut sejalan dengan Macken-Horarik (2007) yang menganggap teks sebagai konstruk sosial yang mempunyai struktur dan fungsi sosial teks yang dapat diidentifikasi dan didekonstruksi. Pembelajaran berbasis teks melibatkan proses dalam membuat teks dan sedikit demi sedikit mengurangi bantuan guru hingga peserta didik mampu memproduksi teks

Pembelajaran berbasis proyek memberi kesempatan pembelajar untuk mengkaji topik permasalahan secara mandiri. Tugas guru ialah membantu peserta didik menetapkan tujuan sementara, memantau kemajuan peserta didik untuk memastikan mereka mendapatkan sumber yang mendalam dan pemahaman yang tepat tentang konsep yang sedang diselidiki (Li Defeng, 2015). Keberhasilan dalam menerapkan pembelajaran berbasis proyek pada peserta didik bergantung pada rancangan tahap pembelajaran. Tahap yang dirancang dalam pembelajaran harus dapat menggali penemuan mereka sendiri (Fathurrohman, 2015). Dengan demikian, pembelajaran berbasis teks dan proyek dapat digunakan untuk mendorong tumbuhnya kreativitas peserta didik, kemandirian, dan tanggung jawab peserta didik.

\section{METODE}

Penelitian ini dilakukan pada siswa kelas VII-F MTs Negeri 2 Kota Malang.,Penelitian ini dilakukan dengan menggunakan model pengembangan Walter R. Borg \& Meredith D. Gall (2003), meliputi (1) pengumpulan informasi, meliputi observasi dan studi pendahuluan, (2) perencanaan penelitian, meliputi mengkaji KD dan penjabaran indikator, serta menyusun dan menentukan langkah-langkah pembelajaran, (3) pengembangan produk awal (prototipe), meliputi mengembangkan materi, kegiatan, dan instrumen penilaian cerita pendek, (4) uji coba lapangan awal, meliputi validasi ahli (a) bahan ajar, (b) pembelajaran menulis, (c) ahli agama, dan (d) praktisi, (5) revisi produk awal, meliputi perbaikan produk berdasarkan saran para ahli dan praktisi, (6) uji coba lapangan kepada peserta didik sebagai calon pengguna produk, (7) revisi produk akhir meliputi memperbaiki bahan ajar dari uji lapangan dan memperbaiki produk akhir berupa bahan ajar. Rincian alur dan instrumen yang digunakan dalam mengembangkan bahan ajar menulis cerita pendek bermuatan nilai-nilai kenabian dipaparkan pada gambar 1. Pengolahan data angket yang diperoleh dari ahli, praktisi, dan peserta didik yang telah divalidasi. Data numerik tersebut kemudian dianalisis menggunakan rumus Arikunto (2006).

Penelitian ini menggunakan desain pra-eksperimen One-Group Pretest-Postest Design tanpa ada kelompok pembanding (kontrol). Teknik analisis data pretest dan postest menggunakan uji t dua sampel berhubungan yang dihitung menggunakan SPSS 23. Data uji t dianalisis menggunakan teknik paired sampled t-test, sedangkan analisis normalitas data dilakukan menggunakan uji statistik one-simple kolmogorof-smirnov test.

a.

Rumus mengolah data per butir

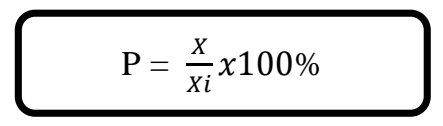

Keterangan

$\mathrm{P} \quad$ : Persentase

$\mathrm{X} \quad$ : Jawaban responden dalam satu butir

xi : Nilai ideal dalam satu butir

$100 \%$ : Konstanta 
b. Rumus mengolah data secara keseluruhan

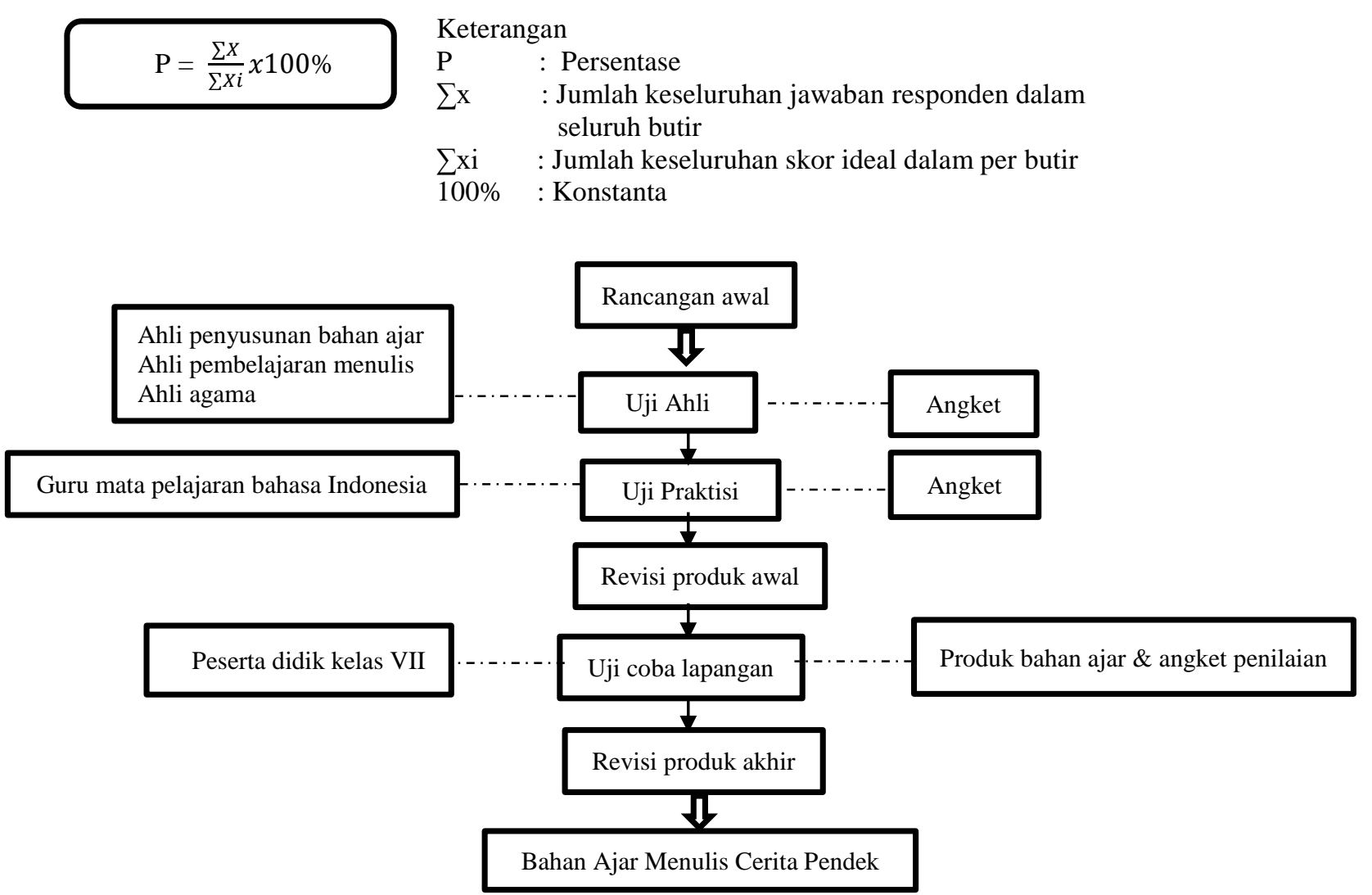

Gambar 1. Desain Uji Coba Produk

\section{HASIL DAN PEMBAHASAN}

Bahan ajar yang dikembangkan bermuatan nilai-nilai kenabian. Pengenalan nilai-nilai kenabian bertujuan agar pembelajar mengetahui bahwa nilai-nilai yang dipelajari dan diketahui selama ini merupakan ajaran nabi. Adanya muatan nilainilai kenabian dalam bahan ajar menulis cerita pendek yang ditujukan pada kelas VII MTs. Diharapkan dapat mengingatkan dan menumbuhkan kesadaran dalam diri peserta didik berkaitan dengan perilaku sebagai seorang muslim, serta dapat mengimplementasikan nilai-nilai kenabian yang telah dipelajari dalam kehidupan sehari-hari. Pengembangan ini menghasilkan buku siswa dan guru yang berjudul Ayo, Rangkai Tulisan dalam Cerita: Tumbuhkan Karakter Nilai Kenabian. Tampilan cover depan bahan ajar yang dikembangkan dipaparkan pada gambar 2 dan 3. Nilai-nilai kenabian yang terkandung dalam bahan ajar dipaparkan pada tabel 1 .

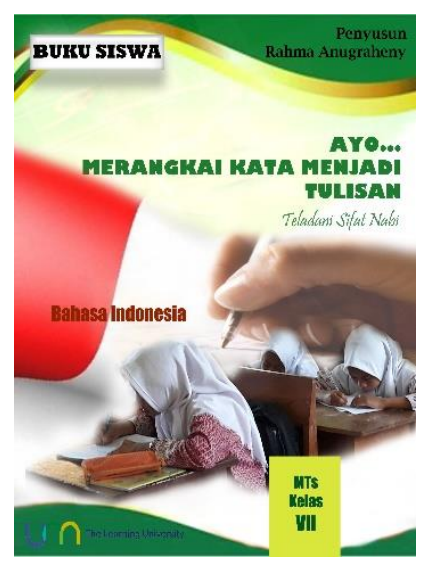

Gambar 2. Sampul Depan Buku Siswa

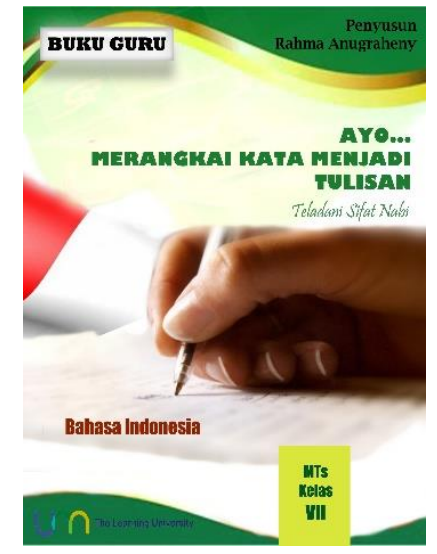

Gambar 3. Sampul Depan Buku Guru 
Tabel 1. Nilai-nilai Kenabian yang Diintegrasikan dalam Teks

\begin{tabular}{|c|c|c|c|c|c|c|c|c|c|}
\hline \multirow{2}{*}{ No } & \multirow{2}{*}{ Judul Karya } & \multicolumn{8}{|c|}{ Nilai Kenabian yang Diintegrasikan } \\
\hline & & NK-1 & NK-2 & NK-3 & NK-4 & NK-5 & NK-6 & NK-7 & NK-8 \\
\hline 1 & Kisah Rasulullah dan Pengemis Tua & & & & & & & & \\
\hline 2 & Kisah Si Ravi yang Sabar & $\sqrt{ }$ & & & & & & & \\
\hline 3 & Kisah Pemuda yang Jujur dan Pedagang yang Korupsi & $\sqrt{ }$ & & $\sqrt{ }$ & & & & & \\
\hline 4 & Indahnya Bersedekah & $\sqrt{ }$ & & $\sqrt{ }$ & & $\sqrt{ }$ & & & \\
\hline 5 & Pelukan Tuhan & $\sqrt{ }$ & $\sqrt{ }$ & $\sqrt{ }$ & $\sqrt{ }$ & $\sqrt{ }$ & $\sqrt{ }$ & $\sqrt{ }$ & $\sqrt{ }$ \\
\hline 6 & Jangan Salahkan Hijabku & $\sqrt{ }$ & $\sqrt{ }$ & $\sqrt{ }$ & $\sqrt{ }$ & $\sqrt{ }$ & $\sqrt{1}$ & $\sqrt{1}$ & $\sqrt{ }$ \\
\hline 7 & Hartaku Tak Bisa Membalas Jasa Kalian & $\sqrt{ }$ & $\sqrt{ }$ & $\sqrt{ }$ & & $\sqrt{ }$ & $\sqrt{ }$ & & \\
\hline 8 & Belajar Bersikap Adil & $\sqrt{ }$ & & $\sqrt{ }$ & & & & & \\
\hline 9 & Khalifah Ali bin Abi Thalib di Pengadilan & $\sqrt{ }$ & & & & & & & \\
\hline 10 & Buah Kejujuran & & & & & & & & \\
\hline
\end{tabular}

Keterangan:

NK (Nilai Kenabian)

1: Kesabaran

2: Keikhlasan

3: Menghormati Orangtua

4: Tidak Mudah Marah

5: Membantu Orang Lain

6: Rajin

7: Jujur

8: Adil

Pengembangan bahan ajar menulis cerita pendek bermuatan nilai-nilai kenabian ini disusun atas dua bab, yaitu bab (1) mengenal teladan nabi melalui cerita pendek, dan (2) menulis kreatif cerita pendek nilai-nilai kenabian. Pada setiap bab tersusun atas empat bagian, yaitu (1) apersepsi, (2) inti pembelajaran, (3) rangkuman, dan (4) refleksi. Pada bab I tersusun atas empat subbab, yaitu (1) mengenali sikap teladan nabi, (2) mengidentifikasi unsur-unsur instrinsik dan ciri kebahasaan cerita pendek, (3) menemukan nilai-nilai kenabian dalam teks cerita pendek, dan (4) menyusun cerita. Keempat subbab tersebut terfokus pada pemahaman peserta didik mengenai cerita pendek. Pada bab II tersusun atas dua subbab, yaitu (1) menemukan ide menulis cerita pendek, dan (2) mengembangkan unsur-unsur pembangun cerita pendek. Kedua subbab tersebut sudah mulai terfokus pada pembimbingan guru kepada peserta didik untuk menulis cerita pendek secara mandiri. Bahan ajar yang telah disusun selanjutnya melalui uji kelayakan, uji keterbacaan, dan uji keefektifan. Berikut dipaparkan hasil ketiga uji bahan ajar tersebut.

\section{Hasil Uji Kelayakan Produk}

Uji kelayakan produk merupakan uji produk dalam bentuk penilaian ahli sebelum dilakukan uji lapangan. Validasi bahan ajar dilakukan oleh ahli (1) bahan ajar, (2) pembelajaran menulis, (3) agama, dan (4) praktisi. Uji kelayakan ini bertujuan agar mengetahui kelayakan bahan ajar sebelum digunakan dalam pembelajaran. Aspek yang divalidasi disesuaikan dengan kriteria kelayakan bahan ajar meliputi kelayakan (1) isi, (2) struktur penyajian, (3) bahasa, dan (4) kegrafikaan. Penyajian hasil uji oleh ahli bahan ajar, pembelajaran menulis, agama, dan praktisi dipaparkan pada tabel 2 dan 3 .

Tabel 2. Rekapitulasi Skor Validasi Ahli Buku Siswa

\begin{tabular}{lccc}
\hline \multicolumn{1}{c}{ Validasi Ahli } & Skor & P & Keterangan \\
\hline Ahli bahan ajar & $78,84 \%$ & & \\
Ahli pembelajaran menulis & $75,97 \%$ & & \\
Ahli bidang agama & $85,71 \%$ & $85,13 \%$ & Layak Diimplementasi \\
Praktisi & $100 \%$ & & \\
\hline
\end{tabular}

Tabel 3. Hasil Uji Buku Guru oleh Para Ahli

\begin{tabular}{lccc}
\hline \multicolumn{1}{c}{ Validasi Ahli } & Skor & P & Keterangan \\
\hline Ahli bahan ajar & $80,76 \%$ & & \\
Ahli pembelajaran menulis & $65,38 \%$ & $83,16 \%$ & Layak Diimplementasi \\
Ahli bidang agama & $98,07 \%$ & & \\
Praktisi & $88,46 \%$ & & \\
\hline
\end{tabular}

Hasil uji buku guru oleh ahli pengembangan bahan ajar memperoleh $\mathrm{P}=80,76$, pembelajaran menulis memperoleh $\mathrm{P}=$ 65,38 , bidang agama memperoleh $\mathrm{P}=98,07$, dan praktisi memperoleh $\mathrm{P}=88,46$. Dengan demikian, produk dinyatakan layak implementasi. Hasil uji kelayakan produk diperoleh dari ahli bahan ajar sebesar 78,84\%, ahli pembelajaran menulis sebesar $75,97 \%$, ahli bidang agama sebesar $85,71 \%$, dan praktisi sebesar $100 \%$. Berdasarkan ketiga skor tersebut, maka diperoleh nilai rata-rata sebesar $85,13 \%$. Dengan demikian, bahan ajar layak diimplementasikan. 


\section{Hasil Uji Keterbacaan}

Analisis tes cloze merupakan tes yang digunakan untuk mengetahui mudah atau tidaknya memahami teks bacaan. Culhane (2016) mengemukakan tingkat keterbacaan terbagi menjadi tiga, yaitu wacana yang tergolong (1) mudah apabila 61\% ke atas, (2) sedang apabila 41-60\%, dan (3) sulit apabila 40\% ke bawah. Berdasarkan hasil uji keterbacaan dengan menggunakan tes cloze kepada 22 peserta didik kelas VII F di MTsN 2 Kota Malang, maka didapat persentase skor rata-rata dari ketiga jenis teks cerita pendek. Persentase skor ketiga teks akan dipaparkan pada tabel 4.

Tabel 4. Rekapitulasi Skor Keterbacaan

\begin{tabular}{lccc}
\hline \multicolumn{1}{c}{ Judul Cerita Pendek } & Skor & P & Kategori \\
\hline Kisah Si Ravi yang Sabar & $73,81 \%$ & & \\
Belajar Bersikap Adil & 63,09 & $63,63 \%$ & Intruksional/sedang \\
Kisah Pemuda yang Jujur dan Pedagang yang Korupsi & $54 \%$ & & \\
\hline
\end{tabular}

Hasil uji keterbacaan diperoleh nilai rata-rata 63,63\% yang diperoleh dari tiga jenis cerita pendek yang berbeda. Dengan demikian, nilai tersebut termasuk bacaan pada kategori intruksional atau sedang.

\section{Hasil Uji Keefektifan Produk}

Hasil uji keefektifan produk didapat dari hasil uji coba menggunakan bahan ajar menulis cerita pendek bermuatan nilainilai kenabian. Uji coba dilakukan dengan delapan kali pertemuan (dua minggu) pembelajaran. Dalam satu minggu berlangsung empat kali pertemuan dengan durasi waktu pembelajaran 80 menit (dua pertemuan) dan 40 menit (dua pertemuan). Hasil perlakuan ini berupa produk cerita pendek yang ditulis oleh peserta didik yang selanjutnya diberi skor, seperti tampak pada tabel 5 .

Tabel 5. Data Skor Menulis Cerita Pendek Bermuatan Nilai-nilai Kenabian

\begin{tabular}{clcccc}
\hline \multirow{2}{*}{ No } & \multirow{2}{*}{ Nama } & \multirow{2}{*}{ L/P } & \multicolumn{2}{c}{ Skor } & \multirow{2}{*}{ Keterangan } \\
\cline { 4 - 5 } & & Pretest & Postest & \\
\hline 1 & ALH & P & 70 & 90 & Meningkat \\
3 & AG & L & 72 & 80 & Meningkat \\
4 & AN & L & 68 & 88 & Meningkat \\
5 & ANA & L & 68 & 90 & Meningkat \\
6 & ANL & P & 78 & 85 & Meningkat \\
7 & AA & P & 68 & 90 & Meningkat \\
8 & BW & L & 73 & 78 & Meningkat \\
9 & DM & L & 80 & 85 & Meningkat \\
10 & FNA & P & 75 & 85 & Meningkat \\
11 & HM & L & 78 & 80 & Meningkat \\
12 & LM & L & 68 & 70 & Meningkat \\
13 & LYS & P & 75 & 80 & Meningkat \\
14 & MRFR & L & 70 & 78 & Meningkat \\
15 & MS & P & 72 & 85 & Meningkat \\
16 & MRAF & L & 68 & 70 & Meningkat \\
17 & MIRQ & L & 75 & 80 & Meningkat \\
18 & MNR & L & 70 & 80 & Meningkat \\
19 & MIK & L & 68 & 75 & Meningkat \\
20 & MAR & P & 72 & 85 & Meningkat \\
21 & NRH & L & 70 & 85 & Meningkat \\
22 & QU & P & 68 & 80 & Meningkat \\
23 & RNA & L & 72 & 78 & Meningkat \\
24 & ROA & P & 67 & 85 & Meningkat \\
25 & ZZIB & L & 65 & 65 & Tetap \\
\hline
\end{tabular}

Berdasarkan tabel 5, dapat diketahui bahwa 23 peserta didik mengalami peningkatan kemampuan dalam menulis cerita pendek dan dua lainnya masih pada skor yang sama (tidak mengalami peningkatan atau penurunan). Peningkatan skor peserta didik ditunjukkan oleh skor pretest dan postest pembelajaran menggunakan bahan ajar menulis cerita pendek bermuatan nilainilai kenabian. Data skor yang telah ada, selanjutnya dilakukan uji normalitas dan uji beda dengan menggunakan SPSS 23 untuk mengetahui keefektifan produk. 
Uji normalitas data dilakukan untuk mengetahui skor hasil menulis cerita pendek peserta didik terdistribusi secara normal atau tidak. Uji dilakukan dengan menggunakan One-Sample Kolmogorov-Smirnov Test yang dasar pengambilan keputusan, yaitu bila nilai probabilitas (Asymp. Sig) $>0,05$, maka distribusi data normal. Hasil perhitungan uji normalitas data dapat dilihat pada tabel 6 .

Tabel 6. Hasil Uji Normalitas Data

\begin{tabular}{|c|c|c|c|c|}
\hline \multicolumn{5}{|c|}{ One-Sample Kolmogorov-Smirnov Test } \\
\hline & & & Postest & Pretest \\
\hline$N$ & & & 25 & 25 \\
\hline \multirow[t]{2}{*}{ Normal Parameters } & $a, b$ & Mean & 81.0800 & 71.2000 \\
\hline & & Std. Deviation & 6.36344 & 3.84057 \\
\hline Most Extreme & & Absolute & .171 & .183 \\
\hline \multirow{2}{*}{ Differences } & & Positive & .127 & .183 \\
\hline & & Negative & -.171 & -.122 \\
\hline Kolmogorov-Smirnov $Z$ & & & .855 & .913 \\
\hline Asymp. Sig. (2-tailed) & & & .457 & .375 \\
\hline
\end{tabular}

\section{a. Test distribution is Normal.}

b. Calculated from data.

Berdasarkan Tabel 6, data terdistribusi secara normal karena data pretest dan postest memiliki data sig. $>0,05$. Data pretest didapat dengan sig. 0,375 dan postest didapat dengan sig. 0.457. Kedua, uji beda dilakukan setelah diketahui data terdistribusi secara normal. Uji beda menggunakan dua jenis hipotesis, yaitu (1) Ho yang berarti bahwa nilai rata-rata pretest dan postest tidak memiliki perbedaan dengan sig. $>0,05$, dan (2) Ha yang berarti bahwa nilai rata-rata pretest dan postest memiliki perbedaan dengan sig. <0,05. Uji beda (uji t) dilakukan dengan menggunakan teknik paired samples t-test (uji beda sampel berpasangan). Hasil perhitungan uji beda (uji t) ditunjukkan pada tabel 7.

Tabel 7. Hasil Statistik Uji Beda Sampel Berpasangan

\begin{tabular}{|c|c|c|c|c|c|}
\hline \multicolumn{6}{|c|}{ Paired Samples Statistics } \\
\hline & & Mean & $\mathbf{N}$ & Std. Deviation & Std. Error Mean \\
\hline Pair 1 & Postest & 81.0800 & 25 & 6.36344 & 1.27269 \\
\hline & Pretest & 71.2000 & 25 & 3.84057 & .76811 \\
\hline
\end{tabular}

\begin{tabular}{|c|c|c|c|c|c|c|c|c|c|}
\hline & & Mean & $\begin{array}{c}\text { Std. } \\
\text { Deviation }\end{array}$ & $\begin{array}{c}\text { Std. Error } \\
\text { Mean }\end{array}$ & $\begin{array}{r}95 \% \text { Confi } \\
\text { the } 1\end{array}$ & $\begin{array}{l}\text { terval of } \\
e\end{array}$ & & & \\
\hline \multirow{2}{*}{ Pair 1} & \multirow{2}{*}{ Postest-Pretest } & \multirow{2}{*}{9.88000} & \multirow{2}{*}{6.86974} & \multirow{2}{*}{1.37395} & Lower & Upper & $t$ & $d f$ & Sig. (2-tailed) \\
\hline & & & & & 7.04431 & 12.71569 & 7.191 & 24 & .000 \\
\hline
\end{tabular}

Berdasarkan hasil perhitungan uji beda pada tabel 7, maka dapat diketahui bahwa $\mathrm{t}=7,191$ dengan sig. 0,000 yang berarti $<0,05$. Nilai rata-rata pretest dan postest memiliki perbedaan secara signifikan dengan rata-rata (mean) postest didapat 81,0800 dengan SD 6,36344 lebih tinggi daripada nilai rata-rata pretest 71,2000 dengan SD 3,84057. Data tersebut menggambarkan bahwa adanya peningkatan skor peserta didik dalam menulis cerita pendek secara signifikan setelah menggunakan bahan ajar menulis cerita pendek bermuatan nilai-nilai kenabian.

\section{SIMPULAN}

Bahan ajar yang dikembangkan dapat digunakan oleh peserta didik dan guru sebagai buku pendamping dari buku pokok yang telah tersedia di sekolah. Bahan ajar berguna untuk membantu peserta didik menulis cerita pendek dengan mudah dan dapat belajar mandiri, sedangkan guru dapat menggunakannya sebagai referensi tambahan dalam pembelajaran cerita pendek (materi, contoh, dan latihan), serta membantu mengarahkan aktivitas dalam pembelajaran.

Bahan ajar yang dikembangkan ini dapat dimanfaatkan oleh pendidik dan peserta didik agar dapat diaplikasikan, diimplementasikan, dan dikembangkan. Oleh karena itu, perlu adanya (1) pemanfaatan produk, (2) diseminasi produk, dan (3) pengembangan produk lebih lanjut. 


\section{DAFTAR RUJUKAN}

Arikunto, S. (2006). Prosedur Penelitian: Suatu Pendekatan Praktik. Jakarta: PT Rineka Cipta.

Dewey, J. (2008). Experience and Education. The Educational Forum, 50(3), 241-252. https://doi.org/10.1080/00131728609335764

Fathurrohman, M. (2015). Model-model Pembelajaran Inovatif. Yogyakarta: Ar-Ruzz Media.

Hyland, K. (2005). Second Language Writing. New York: Cambridge University.

Li Defeng, C. Z. \& Y. D. (2015). Project-based Learning in Teaching Translation: Students Perceptions. The Interpreter and Translator Trainer. https://doi.org/10.1080/1750399X.2015.1010357

Macken-Horarik, M. (2007). Relativism in the Politics of Discourse: A Response to James Paul Gee. In Constructing Critical Literacies (p. 305). Cresskill, NJ: Hampton Press.

McVey, D. (2008). Why All Writing is Creative Writing. Innovations in Education and Teaching International, 45(3), $289-294$. https://doi.org/DOI: 10.1080/14703290802176204

Musfiroh, T. (2008). Cerdas Melalui Bermain. Jakarta: Grasindo.

Mustofa. (2014). Peningkatan Kemampuan Menulis Syair melalui Penerapan Model Problem Based Learning pada Siswa Kelas V SDI Bayanul Azhar Sumbergempol Tulungagung Tahun Pelajaran 2014/2015. Tesis tidak diterbitkan. Universitas Negeri Malang, Malang.

Sabki, A. A., \& Hardaker, G. (2013). The Madrasah Concept of Islamic Pedagogy. Educational Review, 65(3), 342-356. https://doi.org/10.1080/00131911.2012.668873

Slattery, S. B. \& P. (2014). Prophetic Curriculum Leadership. Religion \& Education, 24(1), 59-69. https://doi.org/10.1080/15507394.1997.11000855

Tan, C., \& Ibrahim, A. (2017). Humanism, Islamic Education, and Confucian Education. Religious Education, 112(4), 394-406. https://doi.org/10.1080/00344087.2016.1225247

Thomson, L. (2013). Learning to Teach Creative Writing. Changing English: Studies in Culture and Education, 20(1), 45-52. https://doi.org/10.1080/1358684X.2012.757060

Walter, R. B., \& Meredith, D. G. (2003). Education Research. Pearson Education Inc. 